\title{
An interesting sidetrack in the tofisopam synthesis: lithium variant of a stereospecific Oppenauer oxidation
}

\author{
Erika Molnárné Samu, Gyula Simig, Judit Halász, and Balázs Volk* \\ Egis Pharmaceuticals Plc., Chemical Research Division, P.O. Box 100, H-1475 Budapest, \\ Hungary \\ E-mail:volk.balazs@egis.hu
}

\begin{abstract}
Dedicated to the memory of Professor Manfred Schlosser in honour of his scientific achievements
\end{abstract}

DOI: http://dx.doi.org/10.3998/ark.5550190.p008.964

\begin{abstract}
In the course of the elaboration of a new manufacturing process of anxiolytic drug tofisopam, a stereospecific lithium-catalyzed Oppenauer-type oxidation was observed. Bromine-lithium exchange on the ethylene ketal of 3-(2-bromo-4,5-dimethoxyphenyl)pentan-2-one followed by quenching with 1 equivalent of 3,4-dimethoxybenzaldahyde gave the corresponding alcohols as a mixture of two diastereomeric racemates. On the other hand, when 2.5 equivalents of the aldehyde were applied, only one of the two alcohol diastereomers could be isolated. The lithium alkoxide precursor of the other diastereomeric alcohol, due to the presence of the excess of benzaldehyde as the oxidant, underwent an Oppenauer-type oxidation to give the corresponding ketone.
\end{abstract}

Keywords: Tofisopam, lithiation, Oppenauer oxidation, stereospecific reaction

\section{Introduction}

Tofisopam (1, marketed under brand names Grandaxin ${ }^{\circledR}$ and Emandaxin ${ }^{\circledR}$ ) is a 2,3benzodiazepine type anxiolytic drug. Its psychopharmacological and clinical profile differ from the widely used 1,4-benzodiazepines, since in contrast to those, tofisopam does not bind to the distinct benzodiazepine binding site of the $\mathrm{GABA}_{\mathrm{A}}(\gamma$-aminobutyric acid) receptor. It is an anxiolytic agent without addiction potential, ${ }^{2-4}$ and without the sedative-hypnotic, muscle relaxant and anticonvulsive side effects generally associated with the use of 1,4-benzodiazepines. 


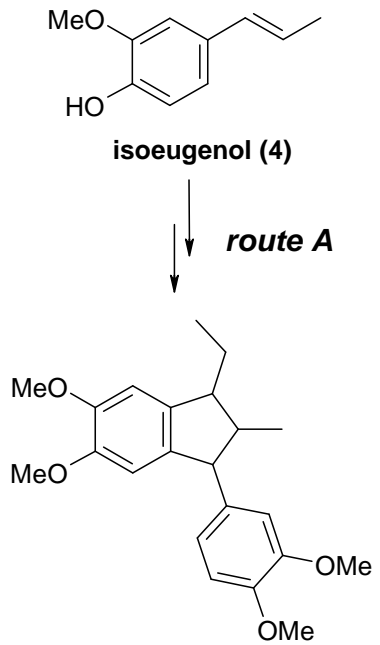

diisohomoeugenol (5)

(mixture of stereoisomers)

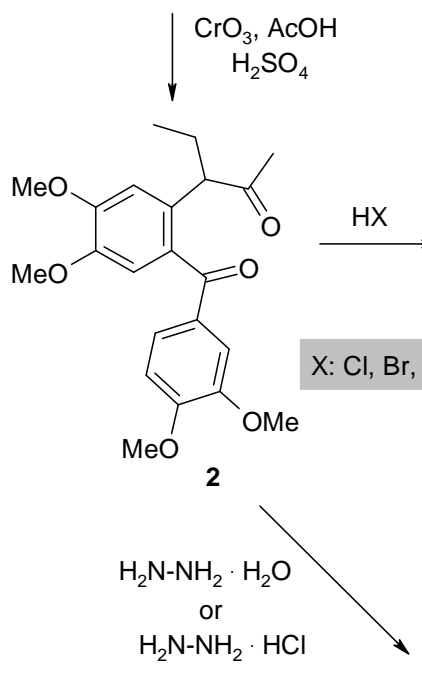<smiles>COc1ccc(CC(C)=O)cc1OC</smiles><smiles>CCCCCCC(c1cc(OC)c(OC)cc1Br)C1(C)OCCO1</smiles>

7

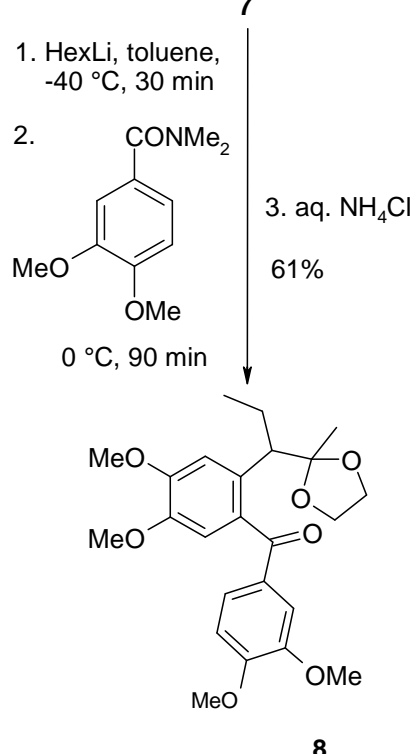

8
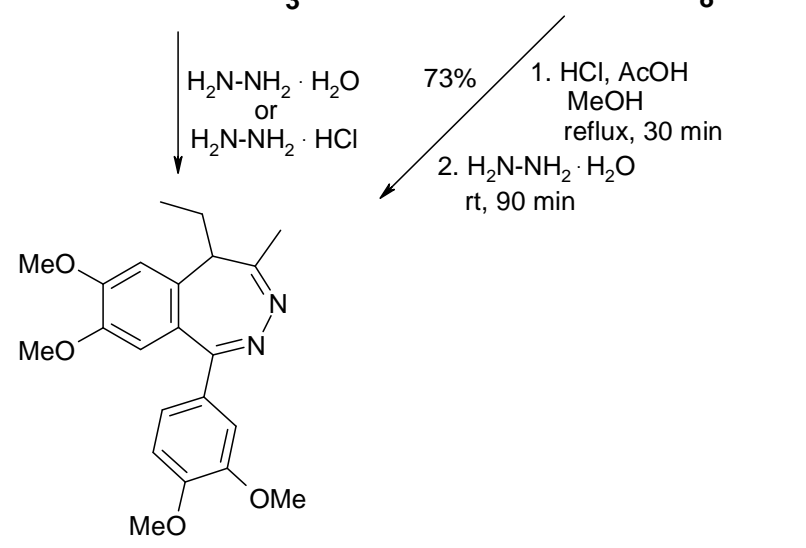

rt, $90 \mathrm{~min}$

tofisopam (1)

\section{Scheme 1}

Tofisopam (1) was obtained by cyclisation of diketone $\mathbf{2}$ or the corresponding 2benzopyrylium salt $\mathbf{3}$ with hydrazine hydrochloride or hydrazine hydrate (Scheme 1, route A). ${ }^{5-6}$ The manufacturing synthesis of key intermediate $\mathbf{2}$ has been based on the natural precursor 
isoeugenol (4), which affords diisohomoeugenol (5) by acid-catalyzed dimerisation ${ }^{7}$ and subsequent $O$-methylation. ${ }^{8}$ Diketone $\mathbf{2}$ was obtained by oxidation of compound $\mathbf{5}$ with chromium(VI) oxide in medium yield. ${ }^{9-13}$

Recently, we have described a new industrial synthesis (Scheme 1, route B) of tofisopam (1), which eliminates the use of the environmentally hazardous chromium reagents. ${ }^{14}$ The commercially available 3,4-dimethoxyphenylacetone (6) was transformed to bromo-ketal 7 by conventional methods. Lithiation with hexyllithium followed by quenching of the lithio species with $\mathrm{N}, \mathrm{N}$-dimethyl-3,4-dimethoxybenzamide gave keto-ketal 8. Removal of the ketal protecting group and cyclization with hydrazine hydrate was carried out in one pot to afford tofisopam (1).

Lebrun et al. described the synthesis of keto-acetal 9, a compound closely related to tofisopam keto-ketal intermediate 8, starting from bromoacetal 10. Bromine-lithium exchange with $t$-BuLi followed by reaction with 0.8 equivalent of 4-benzyloxybenzaldehyde afforded benzhydryl alcohol $\mathbf{1 1}$ in quantitative yield (calculated for the benzaldehyde), which was oxidized with pyridinium dichromate (PDC) to keto-acetal 9 (Scheme 2). ${ }^{15}$

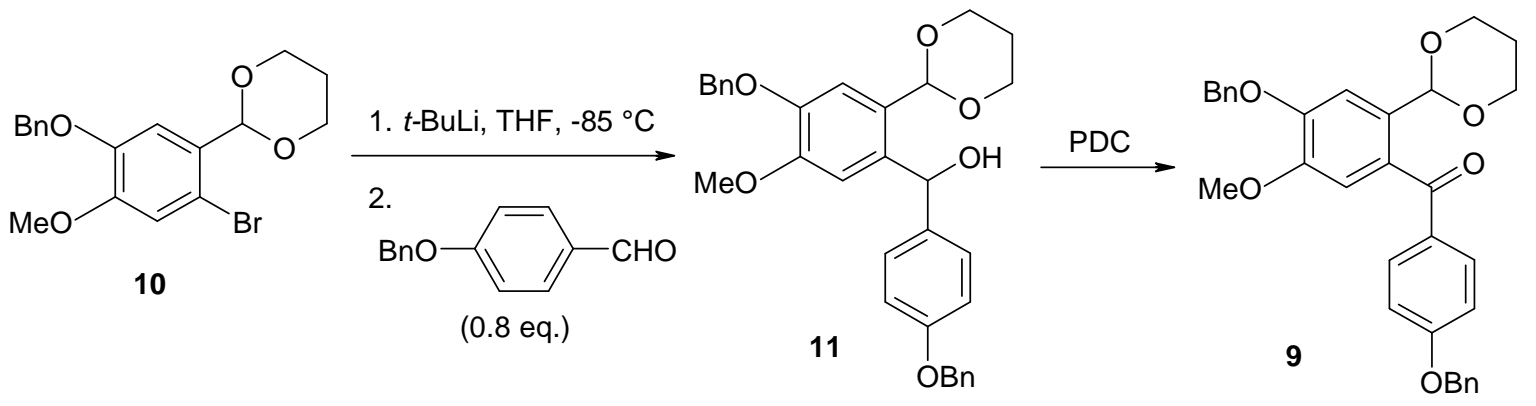

Scheme 2

\section{Results and Discussion}

In the course of our efforts aiming at the elaboration of new manufacturing processes for the synthesis of tofisopam (1), we decided to study a similar route starting from bromo-ketal $\mathbf{7}$ using lithiation chemistry. Quenching of the lithio species, obtained from bromo-ketal 7 by treatment with butyllithium at $-78{ }^{\circ} \mathrm{C}$ with 1 equivalent of 3,4-dimethoxybenzaldehyde gave, via diastereomeric lithium alkoxides $\mathbf{1 3 A}$ and 13B, a crude product containing diastereomeric racemates 12A and 12B in a ratio of 1:1.1 (Scheme 3, route A). After chromatographic work-up, 12A and 12B were obtained in $38 \%$ and $42 \%$ yields, respectively. Since the absolute configuration of the diastereomers is not known, they are characterized by the ${ }^{1} \mathrm{H}$ NMR chemical shift of the methyl group marked on Scheme 3. 


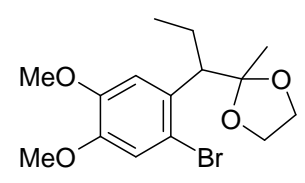

7

BuLi

$-78^{\circ} \mathrm{C}, 2 \mathrm{~h}$

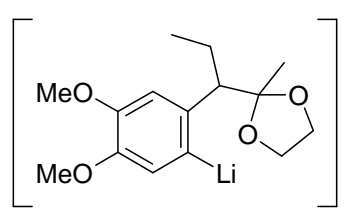

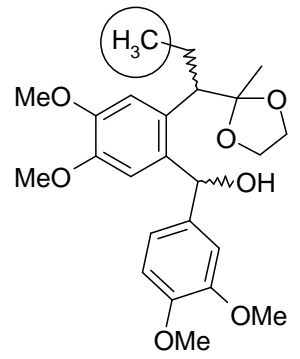

$12 \mathrm{~A}\left(\delta_{\mathrm{CH} 3}: 0.67 \mathrm{ppm}\right)+12 \mathrm{~B}\left(\delta_{\mathrm{CH} 3}: 0.15 \mathrm{ppm}\right)$

route $A$

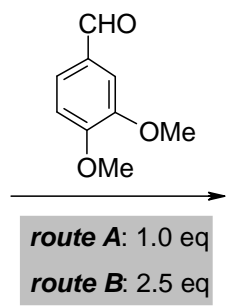

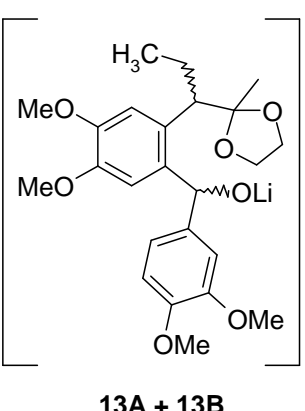

route $B$
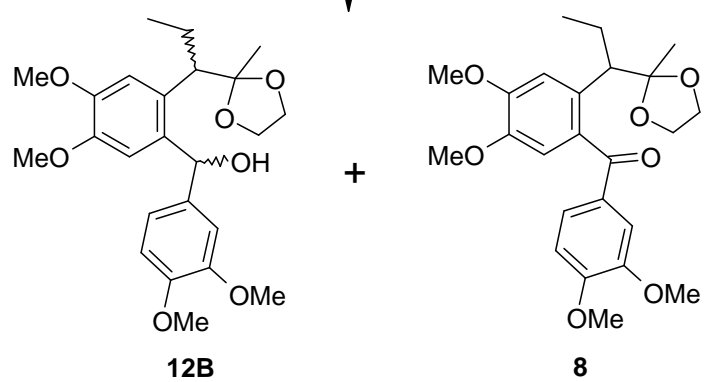

\section{Scheme 3}

In the course of the optimization of the excess of 3,4-dimethoxybenzaldehyde to be used in the reaction, we observed the formation of ketone $\mathbf{8}$ in addition to the alcohols $\mathbf{1 2}$ (Scheme $\mathbf{3}$, route B). Obviously, the excess of benzaldehyde oxidizes the primarily formed lithium alkoxide to ketone 8 in an Oppenauer oxidation process. ${ }^{16,17}$ In the classical Oppenauer oxidation, aluminum isopropoxide is used as the catalyst and acetone as the oxidant. Later on, metal ions other than aluminum and various aldehydes and ketones as oxidants have also been reported. Nevertheless, the only lithium-catalyzed process was disclosed by Capilla et al: lithiation of bromo derivative $\mathbf{1 4}$ followed by reaction with ca. 4 equivalent of 3,4,5-trimethoxybenzaldehyde gave benzophenone 15 in $71 \%$ yield (Scheme 4). ${ }^{18}$ The authors remarked that attempts to isolate 
alcohol $\mathbf{1 6}$ failed due to the fast oxidation of the lithium salt of $\mathbf{1 6}$ to ketone $\mathbf{1 5}$, however, they did not comment on the mechanism of this unique lithium-catalyzed Oppenauer oxidation.<smiles>Brc1ccc2c(c1)OCCO2</smiles>

14
1. BuLi, THF, $-78^{\circ} \mathrm{C}$

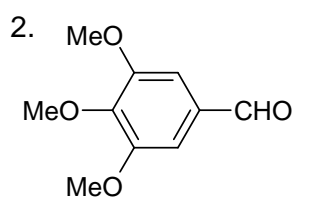

(ca. 4 eq)<smiles>COc1cc(C(O)c2ccc3c(c2)OCCO3)cc(OC)c1OC</smiles>

16<smiles>COc1cc(C(=O)c2ccc3c(c2)OCCO3)cc(OC)c1OC</smiles>

15

\section{Scheme 4}

The magnesium variant of the Oppenauer oxidation was studied in detail (Scheme 5). ${ }^{19}$ Interestingly, the presence of $\mathrm{LiCl}$ in the reaction mixture considerably accelerated the oxidation reaction. It was suggested that the role of $\mathrm{LiCl}$ was both to solubilise the primarily formed magnesium chloride alkoxide and to activate the carbonyl function of benzaldehyde as a Lewis acid.

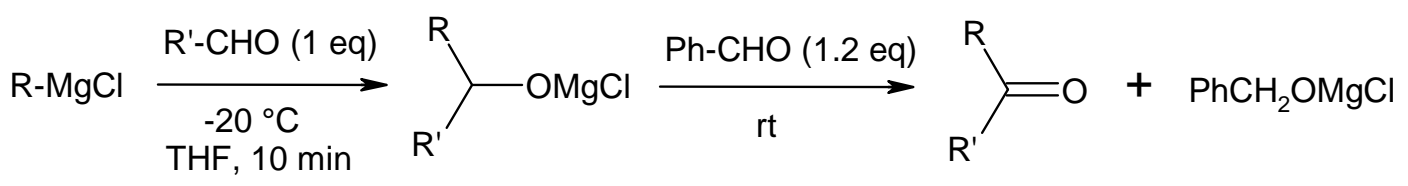

\section{Scheme 5}

Our attempts to achieve full conversion of alcohols $\mathbf{1 2}$ to ketone $\mathbf{8}$, by using a large excess of 3,4-dimethoxybenzaldehyde for quenching the lithium derivative, failed. Finally we realized that under these conditions only one of the diastereomeric alcohols $\mathbf{1 2}$ could be oxidized to ketone $\mathbf{8}$ by the excess of the benzaldehyde. When adding 2.5 equivalents of 3,4-dimethoxybenzaldehyde to the lithiated derivative of bromo-ketal 7, in addition to ketone 8 (43\%), pure unchanged alcohol 12B was also isolated in $35 \%$ yield. Thus, we are facing a stereospecific Oppenauer oxidation in this case.

The stereochemistry of the Meerwein-Ponndorf-Verley reductions of ketones and complementary Oppenauer oxidations (MPVO reactions) using optically active alcohols as chiral sources has been extensively studied. ${ }^{20}$ High stereoselectivities have been mostly observed in intramolecular MPVO reactions, ${ }^{21}$ as illustrated by an example in Scheme $6 .^{22}$ 
<smiles>CC(=O)c1ccccc1OC(C)CC(C)O</smiles><smiles>C#C[Mg]OC(C)c1ccccc1OC(C)CC(C)=O</smiles><smiles>CC(=O)c1ccccc1OC(C)CCO</smiles>

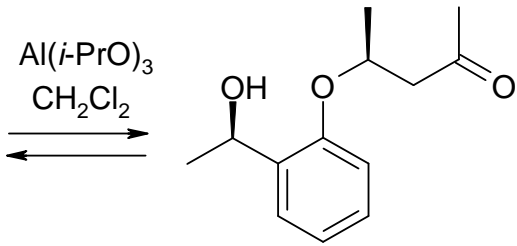

\section{Scheme 6}

A stereospecific Oppenauer oxidation, similar to our case, was observed when a practically equimolar mixture of cis- and trans-4-tert-butylcyclohexanol was treated with acetone as the oxidant in the presence of zeolite beta polymorph A (BEA) catalyst. Only the cis isomer was converted to the corresponding ketone, the trans isomer remained unchanged (Scheme 7). ${ }^{23}$ It appears that the required six-membered transition state, involving a Lewis acid aluminum site in the walls of the micropores of the catalyst, can be formed substantially easier with the cis-alcohol than with the trans one (transition state selectivity).
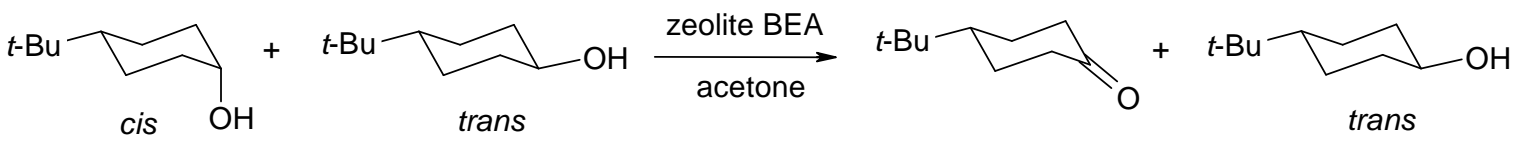

\section{Scheme 7}

The explanation of our observation may also lay in the strict steric requirements of the Oppenauer oxidation. From the diastereomeric lithium salt $\mathbf{1 3 A}$, which leads to $12 \mathrm{~A}$ in the absence of excess aldehyde, an oxidation occurs with the excess aldehyde to give ketone $\mathbf{8}$ via the six-membered transition state coordinated by the lithium ion (17, Scheme 8). 
<smiles>CC[C@H](c1cc(OC)c(OC)cc1[C@H](O[AlH2])c1ccc(OC)c(OC)c1)C1(C)OCCO1</smiles>

$13 A$<smiles>CC[C@H](CO)C1(C)OCCO1</smiles>

\section{Scheme 8}

We suppose that in the lithium salt $\mathbf{1 3 B}$, leading to diastereomer $\mathbf{1 2 B}$, the required sixmembered ring transition state can not be formed, probably because the $\mathrm{Li}^{+}$primarily attached to the alkoxide is intramolecularly "captured" by the oxygen atoms of the ketal moiety, ${ }^{24}$ therefore it can not coordinate the aldehyde oxidant, the indispensable participant of the transition state of the Oppenauer oxidation (Scheme 9).

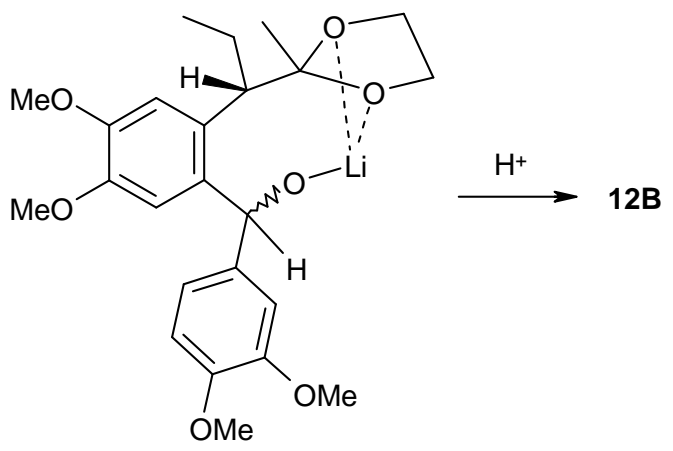

13B

\section{Scheme 9}

Although lithium alkoxide 13B can not be oxidized to ketone $\mathbf{8}$ with excess 3,4dimethoxybenzaldehyde under the Oppenauer conditions, the oxidation of the corresponding alcohol 12B with PDC proceeds in high yield (89\%) in dichloromethane. The analogous PDC oxidations starting from the other diastereomer racemate $(\mathbf{1 2 A})$ or from the mixture of $12 \mathrm{~A}$ and 12B (ratio: 1:1.1) have also been carried out affording tofisopam intermediate $\mathbf{8}$ in high yields ( 85 and $88 \%$, respectively). Keto-ketal $\mathbf{8}$ can be transformed to tofisopam (1) as described in our earlier publication. ${ }^{14}$ 
Computational studies for the explanation of the stereospecific character of the Oppenauer oxidation discussed above, together with efforts to assign the absolute configuration of diastereomers $\mathbf{1 2 A}$ and $\mathbf{1 2 B}$ are in progress.

\section{Conclusions}

A new manufacturing process of anxiolytic drug tofisopam was elaborated. Bromine-lithium exchange on ethylene ketal of 3-(2-bromo-4,5-dimethoxyphenyl)pentan-2-one (7) followed by reaction with 1 equivalent of 3,4-dimethoxybenzaldahyde gave a mixture of diastereomeric alcohols (12A and 12B racemates), which can be oxidized with pyridinium dichromate to the known keto-ketal key intermediate $\mathbf{8}$ of tofisopam (1). This approach also uses an environmentally hazardous chromium reagent, although in much smaller quantity than the widely applied process based on the $\mathrm{CrO}_{3}$ oxidation of diisohomoeugenol.

On the other hand, when 2.5 equivalents of the aldehyde were applied in the reaction with the lithium derivative of compound 7, only one of the two alcohol diastereomers could be isolated. The lithium alkoxide precursor of the other diastereomeric alcohol, due to the presence of the excess of benzaldehyde as the oxidant, underwent a fully stereospecific Oppenauer-type oxidation to give the corresponding keto-ketal 8. Similar lithium-catalyzed Oppenauer oxidations are very scarcely investigated in the literature.

\section{Experimental Section}

General. All melting points were determined on a Büchi 535 capillary melting point apparatus. IR spectra were obtained on a Bruker ALPHA-T FT spectrometer as neat. ${ }^{1} \mathrm{H}$ NMR and ${ }^{13} \mathrm{C}$ NMR spectra were recorded on a Bruker Avance III 400 spectrometer (400 and $100 \mathrm{MHz}$ for ${ }^{1} \mathrm{H}$ and ${ }^{13} \mathrm{C}$ NMR nuclei, respectively). DMSO- $d_{6}$ was used as solvent and tetramethylsilane (TMS) as internal standard. Chemical shifts $(\delta)$ and coupling constants $(J)$ are given in ppm and in $\mathrm{Hz}$, respectively. Elemental analyses were performed on a Perkin-Elmer 2400 analyzer. The reactions were followed by analytical thin layer chromatography on silica gel $60 \mathrm{~F}_{254}$. All unspecified reagents were purchased from commercial sources.

Lithiation of 2-[1-(2-bromo-4,5-dimethoxyphenyl)propyl]-2-methyl-1,3-dioxolane (7) and subsequent reaction with 3,4-dimethoxybenzaldehyde. Procedure A (utilizing 1 equivalent of 3,4-dimethoxybenzaldehyde): The solution of 2-[1-(2-bromo-4,5-dimethoxyphenyl)propyl]-2methyl-1,3-dioxolane $(7,17.26 \mathrm{~g}, 50.00 \mathrm{mmol})$ in anhydrous tetrahydrofuran $(170 \mathrm{~mL})$ was cooled to $-78{ }^{\circ} \mathrm{C}$, then butyllithium $(2.5 \mathrm{M}$ solution in hexanes, $24 \mathrm{~mL}, 60 \mathrm{mmol})$ was added under stirring over a period of $45 \mathrm{~min}$. The mixture was stirred at $-78{ }^{\circ} \mathrm{C}$ for further $1 \mathrm{~h}$, then 3,4-dimethoxybenzaldehyde $(8.31 \mathrm{~g}, 50.0 \mathrm{mmol})$ was added. The stirring was continued for 20 
min at $-78{ }^{\circ} \mathrm{C}$, then the temperature of the reaction mixture was allowed to rise to $0{ }^{\circ} \mathrm{C}$. A saturated $\mathrm{NH}_{4} \mathrm{Cl}$ solution $(150 \mathrm{~mL})$ was added. After stirring for 10 min at $0{ }^{\circ} \mathrm{C}$ the mixture was extracted with ethyl acetate $(2 \times 200 \mathrm{~mL})$. The organic layer was washed with brine, dried over $\mathrm{MgSO}_{4}$, filtered and evaporated.

The residue was purified by column chromatography using hexane-ethyl acetate $(7: 3)$ as the eluent. 5-Dimethoxy-2-[1-(2-methyl-1,3-dioxolan-2-yl)propyl]phenyl\}(3,4-dimethoxyphenyl)methanol (17.3 g, 80\%) was obtained as a mixture of the two diastereomeric racemates 12A and 12B in a molar ratio of 1:1.1 (by ${ }^{1} \mathrm{H} \mathrm{NMR}$ ). After a further run of column chromatography using hexane-ethyl acetate (9:1) as the eluent, 12A (8.20 g, 38\%) and 12B (9.00 g, 42\%) were obtained in pure form as colorless oils.

Compound 12A. TLC: $R_{f}=0.60\left(\mathrm{SiO}_{2}\right.$, ethyl acetate-hexane 2:1). IR (neat): 3506, 2962, 2836, 1606, $1262 \mathrm{~cm}^{-1} .{ }^{1} \mathrm{H}$ NMR (DMSO- $\left.d_{6}, 400 \mathrm{MHz}\right): 6.99(\mathrm{~s}, 1 \mathrm{H}), 6.96(\mathrm{~s}, 1 \mathrm{H}), 6.90(\mathrm{~d}, J=1.6 \mathrm{~Hz}$, $1 \mathrm{H}), 6.87(\mathrm{~d}, J=8.3 \mathrm{~Hz}, 1 \mathrm{H}), 6.82(\mathrm{dd}, J=8.3,1.6 \mathrm{~Hz}, 1 \mathrm{H}), 5.84(\mathrm{~d}, J=4.9 \mathrm{~Hz}, 1 \mathrm{H}), 5.48(\mathrm{~d}, J$ $=4.9 \mathrm{~Hz}, 1 \mathrm{H}), 3.87(\mathrm{~m}, 1 \mathrm{H}), 3.78(\mathrm{~m}, 1 \mathrm{H}), 3.75(\mathrm{~m}, 1 \mathrm{H}), 3.71(\mathrm{~s}, 3 \mathrm{H}), 3.70(\mathrm{~m}, 1 \mathrm{H}), 3.69(\mathrm{~s}$, $3 \mathrm{H}), 3.68(\mathrm{~s}, 3 \mathrm{H}), 3.67(\mathrm{~s}, 3 \mathrm{H}), 3.16(\mathrm{dd}, J=10.9,3.1 \mathrm{~Hz}, 1 \mathrm{H}), 1.85(\mathrm{~m}, 1 \mathrm{H}), 1.54(\mathrm{~m}, 1 \mathrm{H}), 0.70$ $(\mathrm{s}, 3 \mathrm{H}), 0.67$ (t, $J=7.4 \mathrm{~Hz}, 3 \mathrm{H}) \mathrm{ppm} .{ }^{13} \mathrm{C}$ NMR (DMSO- $\left.d_{6}, 100 \mathrm{MHz}\right): 148.46,147.73,147.49$, 146.81, 138.09, 137.07, 131.04, 119.48, 111.53, 111.49, 111.40, 111.25, 110.75, 70.74, 65.16, 63.98, 55.70, 55.68, 55.60, 55.46, 48.49, 23.73, 23.06, $12.01 \mathrm{ppm}$. HSQC (optimized for $J_{\mathrm{C}-\mathrm{H}}=$ $145 \mathrm{~Hz}): 6.99-111.25,6.96-110.75,6.90-111.40,6.87-111.49,6.82-119.48,5.84-70.74,3.87-$ 65.16, 3.78-63.98, 3.75-63.98, 3.71-55.70, 3.70-65.16, 3.69-55.68, 3.68-55.60, 3.67-55.46, 3.1648.49, 1.85-23.73, 1.54-23.73, 0.70-23.06, 0.67-12.01. HMBC (optimized for $J_{\mathrm{C}-\mathrm{H}}=7 \mathrm{~Hz}$, characteristic cross-peaks): 6.99-137.07, 6.96-131.04, 6.87-138.09, 3.71-147.73, 3.69-147.49, 3.68-146.81, 3.67-148.46, 3.16-137.07, 3.16-131.04, 1.54-131.04. Selective 1D NOESY: 6.993.69, 1.54, 0.70; 6.96-3.68; 6.90-3.67. Anal. Calcd. for $\mathrm{C}_{24} \mathrm{H}_{32} \mathrm{O}_{7}$ (432.52): C 66.65, H 7.46\%. Found: C 66.88, H 7.46\%.

Compound 12B. TLC: $R_{f}=0.50\left(\mathrm{SiO}_{2}\right.$, ethyl acetate-hexane 2:1). IR (neat): 3507, 2962, 2836, 1606, $1261 \mathrm{~cm}^{-1} .{ }^{1} \mathrm{H}$ NMR (DMSO- $\left.d_{6}, 400 \mathrm{MHz}\right): 7.17$ (s, 1H), $6.86(\mathrm{~d}, J=8.1 \mathrm{~Hz}, 1 \mathrm{H}), 6.96$ (s, $1 \mathrm{H}), 6.85(\mathrm{~d}, J=1.6 \mathrm{~Hz}, 1 \mathrm{H}), 6.80(\mathrm{~d}, J=1.7 \mathrm{~Hz}, 1 \mathrm{H}), 6.74(\mathrm{dd}, J=8.1,1.7 \mathrm{~Hz}, 1 \mathrm{H}), 5.87(\mathrm{~d}, J$ $=4.5 \mathrm{~Hz}, 1 \mathrm{H}), 5.46(\mathrm{~d}, J=4.5 \mathrm{~Hz}, 1 \mathrm{H}), 3.86(\mathrm{~m}, 1 \mathrm{H}), 3.81(\mathrm{~m}, 1 \mathrm{H}), 3.73(\mathrm{~s}, 3 \mathrm{H}), 3.701(\mathrm{~s}, 3 \mathrm{H})$, $3.699(\mathrm{~s}, 3 \mathrm{H}), 3.65(\mathrm{~s}, 3 \mathrm{H}), 3.63(\mathrm{~m}, 1 \mathrm{H}), 3.02(\mathrm{dd}, J=11.0,3.6 \mathrm{~Hz}, 1 \mathrm{H}), 1.69(\mathrm{~m}, 1 \mathrm{H}), 1.55(\mathrm{~m}$, $1 \mathrm{H}), 1.14(\mathrm{~s}, 3 \mathrm{H}), 0.15(\mathrm{t}, J=7.4 \mathrm{~Hz}, 3 \mathrm{H}) \mathrm{ppm} .{ }^{13} \mathrm{C}$ NMR (DMSO- $\left.d_{6}, 100 \mathrm{MHz}\right): 148.54$, 147.97, 147.19, 146.91, 138.08, 137.37, 129.84, 120.11, 111.80, 111.48, 111.43, 111.34, 110.09, $70.98,64.92,64.41,55.78,55.72,55.62,55.50,48.31,23.10,22.79,11.72$ ppm. HSQC (optimized for $J_{\mathrm{C}-\mathrm{H}}=145 \mathrm{~Hz}$ ): 7.17-110.09, 6.86-111.48, 6.85-111.43, 6.80-111.80, 6.74-120.11, 5.87-70.98, 3.86-64.92, 3.81-64.41, 3.73-55.50, 3.701-55.72, 3.699-55.78, 3.65-55.62, 3.63$64.92,3.02-48.31,1.69-22.79,1.55-22.79,1.14-23.10,0.15-11.72$. HMBC (optimized for $J_{\mathrm{C}-\mathrm{H}}=$ $7 \mathrm{~Hz}$, characteristic cross-peaks): 7.17-147.19, 137.37, 129.84, 70.98; 6.80-147.97; 6.74-148.54; $5.46-70.98 ; 3.73-146.91 ; 3.701-147.97 ; 3.699-147.19 ; 3.65-148.54 ; 3.02-137.37$, $129.84 ; 1.55-$ 129.84; 1.14-111.34, 48.31. Selective 1D NOESY: 7.17-3.73, 5.46; 6.80-5.87, 5.46, 3.65. Anal. Calcd. for $\mathrm{C}_{24} \mathrm{H}_{32} \mathrm{O}_{7}$ (432.52): C 66.65, H 7.46\%. Found: C 66.65, H 7.34\%. 
Procedure B (utilizing 2.5 equivalent of 3,4-dimethoxybenzaldehyde): The solution of 2-[1-(2bromo-4,5-dimethoxyphenyl)propyl]-2-methyl-1,3-dioxolane (7, $17.26 \mathrm{~g}, 50.00 \mathrm{mmol})$ in anhydrous tetrahydrofuran $(170 \mathrm{~mL})$ was cooled to $-78{ }^{\circ} \mathrm{C}$, then butyllithium $(2.5 \mathrm{M}$ solution in hexanes, $24 \mathrm{~mL}, 60 \mathrm{mmol}$ ) was added under stirring over a period of $45 \mathrm{~min}$. The mixture was stirred at $-78{ }^{\circ} \mathrm{C}$ for further $1 \mathrm{~h}$, then 3,4-dimethoxybenzaldehyde $(20.77 \mathrm{~g}, 125.0 \mathrm{mmol})$ was added. The stirring was continued for $20 \mathrm{~min}$ at $-78{ }^{\circ} \mathrm{C}$, then the temperature of the reaction mixture was allowed to rise to room temperature and heated to reflux. Reflux temperature was maintained for $2 \mathrm{~h}$, the reaction mixture was cooled to ambient temperature. A saturated $\mathrm{NH}_{4} \mathrm{Cl}$ solution $(150 \mathrm{~mL})$ was added. After stirring for $10 \mathrm{~min}$, the mixture was extracted with ethyl acetate $(2 \times 200 \mathrm{~mL})$. The organic layer was washed with brine, dried over $\mathrm{MgSO}_{4}$, filtered and the filtrate was evaporated. A crude product $(38.0 \mathrm{~g})$ was obtained containing compounds $\mathbf{1 2 B}$ and

\{4,5-dimethoxy-2-[1-(2-methyl-1,3-dioxolan-2-yl)propyl]phenyl $\}(3,4-$ dimethoxyphenyl)methanone (8). Compound 12A could not be detected by ${ }^{1} \mathrm{H}$ NMR. Separation by column chromatography using hexane-ethyl acetate (7:3) as the eluent gave, after trituration with EtOH at $0{ }^{\circ} \mathrm{C}, 8(9.20 \mathrm{~g}, 43 \%)$ as off-white crystals and alcohol 12B $(7.50 \mathrm{~g}, 35 \%)$ as an oil. Melting point $\left(165-166^{\circ} \mathrm{C}\right)$ and spectral data of compound $\mathbf{8}$ are in accord with the literature. ${ }^{14}$

Preparation of 8 by oxidation of 12A with PDC. To a solution of alcohol 12A (2.16 g, 5.00 $\mathrm{mmol})$ in dichloromethane $(40 \mathrm{~mL})$ was added PDC $(2.82 \mathrm{~g}, 7.44 \mathrm{mmol})$, and the reaction mixture was stirred for $6 \mathrm{~h}$. The mixture was filtered and the filtrate was washed with an aqueous $\mathrm{Na}_{2} \mathrm{CO}_{3}$ solution $(40 \mathrm{~mL})$ and the layers were separated. The organic layer was washed with brine, dried over $\mathrm{MgSO}_{4}$, filtered and evaporated. The crude product thus obtained (2.20 g) was purified by column chromatography using hexane-ethyl acetate (7:3) as the eluent to afford compound 8 ( $1.83 \mathrm{~g}, 85 \%)$.

Preparation of 8 by oxidation of 12B with PDC. One proceeds as described above for 12A, starting from 12B (2.16 g, $5.00 \mathrm{mmol})$ to obtain compound $\mathbf{8}(1.91 \mathrm{~g}, 89 \%)$.

Preparation of 8 by oxidation of a mixture of 12A and 12B with PDC. One proceeds as described above for 12A, starting from a mixture of 12A and 12B (ratio: 1:1.1, $2.16 \mathrm{~g}, 5.00$ $\mathrm{mmol})$ to obtain compound $\mathbf{8}(1.89 \mathrm{~g}(88 \%))$.

\section{References}

1. Tofisopam official monograph, Japanese Pharmacopoeia, Sixteenth Edition, p. 1511.

2. Berényi, E.; Blaskó, G. Acta Pharm. Hung. 1993, 63, 45-51.

3. Horváth, E.; Palkovits, M.; Lenkei, Zs.; Gyüre, K.; Fekete, M. I. K.; Arányi, P. Mol. Brain. Res. 1994, 22, 211-218.

http://dx.doi.org/10.1016/0169-328X(94)90049-3

4. Horváth, E. J.; Horváth, K.; Hámori, T.; Fekete, M. I. K.; Sólyom, S.; Palkovits, M. Prog. Neurobiol. 2000, 60, 309-342.

http://dx.doi.org/10.1016/S0301-0082(99)00020-9 
5. Körösi, J.; Láng, T. Chem. Ber. 1974, 107, 3883-3893. http://dx.doi.org/10.1002/cber.19741071219

6. Körösi, J.; Láng, T.; Komlós, E.; Erdélyi, L. Hungarian Pat. HU 155572, 1966; Chem. Abstr. 1969, 70, 115026.

7. Beniczky, F.; Papp, T.; Simonyi, I.; Drozdik, Gy.; Kékesi, T.; Derczbach, I. Hungarian Pat. HU 191225, 1981; Chem. Abstr. 1984, 100, 85407.

8. Haworth, R. D.; Mavin, C. R. J. Chem. Soc. 1931, 1363-1366. http://dx.doi.org/10.1039/jr9310001363

9. Müller, A.; Hartai, M. Berichte 1942, 75, 891-899.

10. Doering, W. E.; Berson, J. A. J. Am. Chem. Soc. 1950, 72, 1118-1123. http://dx.doi.org/10.1021/ja01159a014

11. Müller, A.; Lempert-Sréter, M.; Karczag-Wilhelms, M. J. Org. Chem. 1954, 19, 1533-1547. http://dx.doi.org/10.1021/jo01374a019

12. Körösi, J.; Szabó-Czibula, G.; Lay-Kónya, A. Hungarian Pat. HU 158091, 1969; Chem. Abstr. 1971, 74, 42168.

13. Balogh, T.; Láng, T.; Körösi, J.; Zólyomi, G.; Botka, P.; Hámori, T.; Somogyi, Gy.; Láng, T. Hungarian Pat. HU 194529, 1984; Chem. Abstr. 1986, 105, 152712.

14. Molnárné Samu, E.; Lukács, Gy.; Volk, B.; Simig, Gy. Heterocycles 2014, 88, 287-295. http://dx.doi.org/10.3987/COM-13-S(S)15

15. Lebrun, S.; Couture, A.; Deniau, E.; Grandclaudon, P. Org. Biomol. Chem. 2003, 1, 17011706. http://dx.doi.org/10.1039/b302168h

16. de Graauw, C. E.; Peters, J. A.; van Bekkum, H.; Huskens, J. Synthesis 1994, 1007-1017. http://dx.doi.org/10.1055/s-1994-25625

17. Graves, C. R.; Campbell, E. J.; Nguyen, S. T. Tetrahedron: Asymmetry 2005, 16, 3460-3468. http://dx.doi.org/10.1016/j.tetasy.2005.08.058

18. Capilla, A. S.; Romero, M.; Pujol, M. D.; Caignard, D. H.; Renard, P. Tetrahedron 2001, 57, 8297-8303.

http://dx.doi.org/10.1016/S0040-4020(01)00826-2

19. Kloetzing, R. J.; Krasovskiy, A.; Knochel, P. Chem. Eur. J. 2007, 13, 215-227. http://dx.doi.org/10.1002/chem.200600738

20. Nishide, K.; Shigeta, Y.; Obata, K.; Node, M. J. Am. Chem. Soc. 1996, 118, 13103-13104, and references cited therein. http://dx.doi.org/10.1021/ja963098j

21. Molander, G. A.; McKie, J. A. J. Am. Chem. Soc. 1993, 115, 5821-5822. http://dx.doi.org/10.1021/ja00066a059

22. Fujita, M.; Takarada, Y.; Sugimura, T.; Tai, A. J. Chem. Soc. Chem. Commun. 1997, 16311632.

http://dx.doi.org/10.1039/a704341d 
23. Creyghton, E. J.; Ganeshie, S. D.; Downing, R. S.; van Bekkum, H. J. Mol. Catal. A 1997, 115, 457-472.

http://dx.doi.org/10.1016/S1381-1169(96)00351-2

24. A similar coordination is described in: Chastrette, F.; Hassambay, M.; Chastrette, M. Bull. Soc. Chim. France 1976, 607-612. 